\title{
Storytelling in the Psalter? \\ Chances and Limits of a Narrative Psalm Analysis - Shown Exemplarily in Psalm 64
}

\author{
Sigrid Eder (Catholic Private \\ UNIVERSITY LINZ)
}

\begin{abstract}
Storytelling in the psalter is usually attributed to those psalms which relate stories of the history of Israel. Narratology, the theory and procedure of studying narrative representations, is usually applied to narratives. However, there are certain features in the psalms, which allow us to define them as narrative texts and therefore examine them by means of narratology. This paper aims to contribute to a genreoverlapping approach towards poetry by means of opening the way to showing the benefits, as well as limitations of narratology applied to poetical texts by applying the narratological categories narrator/ narrative voice, plot/build-up of tension, characters and characterization, as well as time and space to Psalm. 64.
\end{abstract}

KEYWORDS: Narrative analysis; narratology and poetry; Psalm 64; cross genre approach; metaphors; enemies in Psalm 64; lyrical "I"; image of God.

\section{A INTRODUCTION}

Storytelling in the Bible is usually attributed to narrative texts. If storytelling relates to the psalter, though, it is habitually attributed to those psalms which tell stories about the history of Israel, e.g. Pss 78, 105, 106, 135 and 136. There are, however, certain features in all or most of the psalms except the narrative elements in the headlines, which allow us to define them as narrative texts and therefore examine them by means of the critical lens of narratology. ${ }^{1}$

* Article submitted: 2019/03/04; peer reviewed: 2019/06/17; accepted: 2019/07/19. Sigrid Eder, "Storytelling in the Psalter? Chances and Limits of a Narrative Psalm Analysis - Shown Exemplarily in Psalm 64," OTE 32 no. 2 (2019): 343-357. DOI: https://doi.org/10.17159/2312-3621/2019/v32n2a5.

$1 \quad$ This paper does not include neither a study of narrative psalm titles which make a connection between the psalms and certain narratives from the Old Testament nor a whole exegesis of the psalm which will be analysed. For a detailed analysis of potentials of readers' identification in Psalm 64 see Sigrid Eder, Identifikationspotenziale in den Psalmen. Emotionen, Metaphern und Textdynamik in den Psalmen 30, 64, 90 und 147 (BBB 183; 2 $2^{\text {nd }}$ ed. Göttingen: Vandenhoeck \& Ruprecht, 2019), 329-370. DOI: https://www.vr-elibrary.de/doi/book/10.14220/9783737006842. 
After having presented definitions of narrativity and having searched for narrative elements in the language of the psalms, the text analysis of Psalm 64 is carried out. By applying the narratological categories narrator/narrative voice, plot/build-up of tension, characters and characterization, as well as time and space to Ps 64, the paper aims to contribute to a genre overlapping approach towards poetry by means of opening the way to showing the benefits, as well as limitations of narratology applied to poetic texts.

There have only been a few attempts to examine lyrical texts in the Bible using narratological categories of analysis. ${ }^{2}$ These attempts serve to widen the scope of the classic repertoire of methods applied in the analysis of poetic texts and by doing so to gain new insights - beyond existing genre borders.

\section{B THEORETICAL BACKGROUND}

\section{Narrative analysis, narrativity and psalms}

Can narrative analysis only be used to analyse narrative texts? This question leads us to the next one, asking for the meaning of narrativity and taking into consideration that narratology widens its subjects of analysis also to drama, images, films and computer games.

So, can psalms be considered as narrative texts? To answer this question, one must find out how narrative texts function and especially how the term narrative can be described and defined. Let's have a look at two descriptions:

Peter Hühn defines it as follows: "Narration is a communicative act in which a chain of happenings is meaningfully structured and transmitted in a particular medium and from a particular point of view." 3 This underlies that also poems represent temporally organized sequences and thus relate "stories": "Lyric poetry in the strict sense typically features strings of happenings

2 For Ps 55 see Yvonne Thöne, "Stay in the Desert, Prowl in the City. A Narratological Analysis of Psalm 55," in Mótun menningar: afmoelisrit til heiðurs Gunnlaugi A. Jónssyni sextugum = Shaping Culture: A Festschrift in Honor of Gunnlaugur A. Jónsson on his Sixtieth Birthday (ed. Kristinn Ólason et al.; Reykjavík: Hiđ Íslenska Bókmenntafélag, 2012), 55-73. For the Song of Songs see Stefan Fischer, Das Hohelied Salomos zwischen Poesie und Erzählung. Erzähltextanalyse eines poetischen Textes (FAT 72; Tübingen: Mohr Siebeck, 2010) and Yvonne Thöne, Liebe zwischen Stadt und Feld. Raum und Geschlecht im Hohelied (EZ 22; Berlin: LIT, 2012). 3 Cf. Peter Hühn and Roy Sommer, "Narration in Poetry and Drama," Paragraph 2, in The Living Handbook of Narratology (eds. P. Hühn et al.; Hamburg: Hamburg University Press, 2016), https://wikis.sub.uni-hamburg.de/lhn/index.php/Narration_in _Poetry_and_Drama. 
perceived through the consciousness of single speakers and articulated from their position."4

Wolf Schmidt's description of narrativity implies the existence of a narrative voice and a chain of events. ${ }^{5}$

When we look at the psalms, we can indeed find 1) a narrative voice, the lyrical "I" or "We", relating 2) strings of happenings or chains of events from 3) a certain point of view. So, psalms can be approached in the same way as narrative texts and certainly have (some of) the same narratological characteristics. ${ }^{6}$

\section{Narratology}

Narratology can be performed on three levels: On the level of the theory of narration, (theoretically oriented narratology), on the level of the history of narration (historically oriented narratology) and on the level of narrative analysis (applied narratology). ${ }^{7}$ The last level, applied narratology or narrative analysis is the relevant one for this paper. On this level of narrative analysis, a distinction is made between the three parameters "the who", "the what" and "the how" of a narration: Who tells the story (parameter of the narrator)? What is told by the narrator (parameter of the story) and how is this all presented (parameter of the discourse) $?^{8}$

Gérard Genette makes a distinction here between narration (the narrative act of the narrator), discours or récit proper (narrative as text or utterance) and histoire (the story the narrator tells in his/her narrative)."9 The narrative analysis in this paper will focus on the story level or, according to Genette, the histoire. Thus, I will examine the poetical text with the following five categories of

\footnotetext{
4 Ibid., 2.

5 Cf. Wolf Schmid, Elemente der Narratologie (2 ${ }^{\text {nd }}$ ed.; Berlin: De Gruyter, 2008), 1-10. "Die Minimalbedingungen der Narrativität ist, dass mindestens eine Veränderung eines Zustandes in einem angegebenen zeitlichen Moment dargestellt wird" (4). "Narrativ im engeren Sinne, so mein Vorschlag, sollen Texte genannt warden, die eine Geschichte denotieren und eine die Geschichte vermittelnde Instanz (einen 'Erzähler') entweder explizit oder implizit mit darstellen" (9).

6 Ilse Müllner, "Zeit, Raum, Figuren, Blick. Hermeneutische und methodische Grundlagen der Analyse biblischer Erzähltexte," PZB 15 (2006): 1-24 (17) states: "Narratologische Fragestellungen sind mit Sicherheit auch dann angemessen, wenn es um biblische Texte geht, die gewöhnlich nicht als Erzählungen betrachtet werden."

7 Cf. Jörg Schönert, "Was ist und was leistet Narratologie? Anmerkungen zur Geschichte der Erzählforschung und ihrer Perspektiven," Literaturkritik 8(4) (2006): Section II, https://literaturkritik.de/id/9336.

$8 \quad$ Cf. Silke Lahn and Jan C. Meister, Einführung in die Erzähltextanalyse $\left(^{\text {nd }}\right.$ ed.; Stuttgart: J.B. Metzler, 2013), 61.101.199.

9 Monika Fludernik, An Introduction to Narratology (London: Routledge, 2009), 2.
} 
narrative analysis trying to find out the chances as well as the limits of a narrative psalm analysis:

1. story/build-up of tension;

2. narrator/narrative voice;

3. characters and characterization;

4. time;

5. space and movement.

Following Gérard Genette's definition, I use the term story - like "histoire" or "fabula" or "fable" or "Geschichte" - for the chronological sequence of events.

There are several psalms well suited for such an analysis of text-internal narrative structures, such as, for example, Ps 30 with its two miniature short stories or hymnal Ps 147 with its three separate scenes. I have chosen Ps 64 because of its high degree of narrativity and its exceptional narrative structure telling us one continuous story and can thus be analysed as one. Furthermore, several synthetic parallelisms can be found in Ps 64 describing the continuation of the plot. And finally, Ps 64 is well known and analysed by Phil Botha not only for its wisdom elements.

\section{TEXT ANALYSIS}

\section{Text and Working Translation of Psalm $64^{10}$}

1 1 To the chief Musician. A Psalm. In the spirit of David.

20 2arear, God, my voice in my complaint.

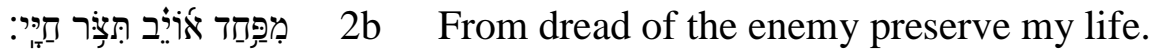

3a Hide me from the counsel of evildoers,

3b from the tumult of those who do evil,

4a who have sharpened their tongues like a sword

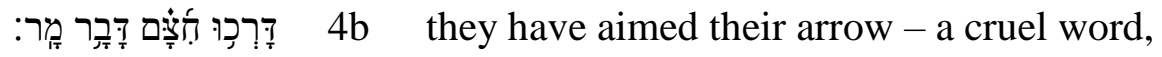

5a to shoot from hiding at the blameless/innocent.

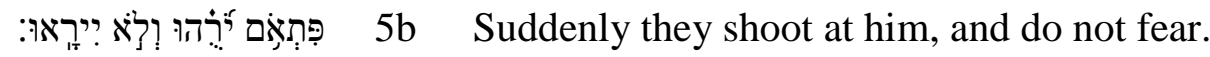

6a

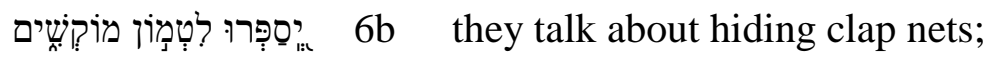

6colno they say, "Who will see them?"

7a 7 They plot injustice:

7b "We have devised a perfect plan!" /

10 The structuring of units of expression in my working translation of Ps 64 follows Jan P. Fokkelman, The Psalms in Form. The Hebrew Psalter in its Poetic Shape (BSS 4; Leiden: Deo, 2002), 72. 


\begin{tabular}{|c|c|c|}
\hline 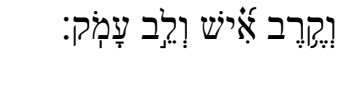 & 7 & $\begin{array}{l}\text { And the human mind, the heart } \\
\text { unfathomable. }\end{array}$ \\
\hline 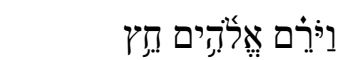 & $8 \mathrm{a}$ & And then God shot an arrow at them. \\
\hline 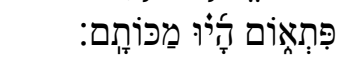 & $8 b$ & Suddenly their wounds were there. \\
\hline 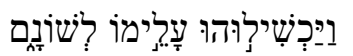 & $9 \mathrm{a}$ & They were brought down by their own tongues \\
\hline 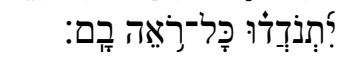 & $9 b$ & All who saw this, were shuddering. \\
\hline 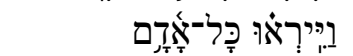 & $10 \mathrm{a}$ & Then everyone feared, \\
\hline 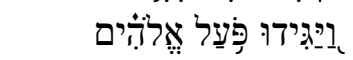 & $10 b$ & and they proclaimed the work of God \\
\hline 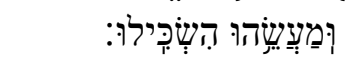 & $10 \mathrm{c}$ & and his deed they perceived. \\
\hline 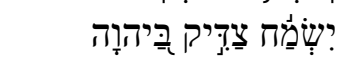 & $11 \mathrm{a}$ & The righteous shall rejoice in YHWH \\
\hline 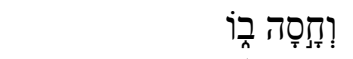 & $11 b$ & and take refuge in him. \\
\hline . 18 & $11 \mathrm{c}$ & All the upright in heart shall exalt. \\
\hline
\end{tabular}

Psalm 64 is constructed like a retrospective telling of the hardship caused by the enemies, the intervention and the subsequent reaction. The content is depicted as if the words and deeds of the past were present now: ${ }^{11}$ The following events and descriptions can be found in the story of the psalm which lays out a sequence of events:

Someone who is beset by enemies asks God for his protection. The enemies are those who with their sharp tongues seem to shoot arrows at the innocent. They do this all of a sudden and without fear, neither fearing God nor human beings. Their weapons are evil words and malign thoughts. But all this falls back on them, as God shoots an arrow on them and suddenly wounds appear. The enemies stumble over their own tongues. All those who see it, are struck with fear (of God), proclaim and finally understand the deeds of God. The psalm ends with the conclusion that the just can rejoice and hide in YHWH, and a prospect of all upright in heart who shall exalt.

\section{Narrative voice and structure}

The narrative voice can be presumed as a continuous lyrical "I" raising his/her voice at the beginning of the psalm (vv. 2-3) and later receding into the background behind a narrative voice telling the story.

Psalm 64 can be divided into two parts: vv. $1-7$ and vv. $8-11 ;{ }^{12}$ criteria for this structure can be seen in the change of subject and theme, but also of narrative

11 Cf. Beat Weber, Werkbuch Psalmen 1. Die Psalmen 1 bis 72 (Stuttgart: Kohlhammer, 2001), 285.

12 Cf. e.g. Artur Weiser, Die Psalmen, 1. Teil (ATD 14; $9^{\text {th }}$ ed.; Göttingen: Vandenhoeck \& Ruprecht, 1979), 311; Phil J. Botha, "The Textual Strategy and Social Background of Psalm 64 as Key to its Interpretation," JSem 11 (2002): 64-82 (69) and Richard J. Clifford, Psalms 1-72 (AOTC; Nashville, TN: Abingdon Press, 2002), 298. 
forms (wayyiqtol-forms). Below the caption which assigns the psalm to David, part 1 in turn consists of two segments: vv. 2-3 describes how the lyrical "I" asks God to protect him/her from his/her enemies, while vv. 4-7b characterises those enemies. The first part concludes with a statement presenting a wisdom concerning the inner being of human beings (7c). The movement within the text now settles down for a while. Part II first talks about the deed of God against the enemies and its effects (vv. 8-9) as a counter-movement to part I, and later about the consequence of God's intervention for human beings, for those who are just and upright in heart (vv. 10-11). ${ }^{13}$

\section{$3 \quad$ Story and build-up of tension}

From v. 2 on it becomes apparent that psalm 64 is mainly characterised by synthetic, i.e. forward-driving parallelisms. This also shows that the text is dynamic in the sense of a progressing action and build-up of tension. Each new colon adds a nuance or a further detail to the story.

Regarding the build-up of tension, there is a perceptible increase in the description of the enemies' actions. This increase can be divided into the two levels of actions connected to hunting and fight on the one side and inner processes and communication on the other. In connection to the first level, the enemies initially start preparing for the hunt or fight by sharpening their tongues like swords (4a), then they bend the bow and align the arrow (4b); later they shoot, suddenly and from their hiding place (5b.6b). The second level of inner processes and communication leads from a description of safety in the sense of lack of fear (5b), the certainty of not being discovered (6c), through the strength by evil words (6a) and by malign thoughts (7a) to a completed and well-laid-out plan (7b). It is here in $\mathrm{v} .7$ that the story enters a rest period for the first time.

This is followed by the second part of the psalm. On the level of characters, the enemies are probably expecting to triumph. ${ }^{14}$ However, surprisingly, the narrative flow takes a turn here: It is God, who actively and purposefully intervenes in the storyline and foils the triumph of the enemies: The climax of the psalm is reached in vv. 8-9: Unexpectedly (פָּזָאם), God has stepped in, the enemies were brought down. At the end of the text, the tension levels out with the description of the reaction after the divine deed and a conclusion.

13 This structure is among others also applied by Frank-Lother Hossfeld and Erich Zenger, Psalmen 51-100 (HThKAT; Freiburg: Herder, 2000), 204 and Peter Riede, Im Netz des Jägers. Studien zur Feindmetaphorik der Individualpsalmen (WMANT 85; Neukirchen-Vluyn: Neukirchener, 2000), 365.

14 Cf. Valentin Thalhofer, Erklärung der Psalmen und der im römischen Brevier vorkommenden biblischen Cantica, mit besonderer Rücksicht auf deren liturgischen Gebrauch ( $9^{\text {th }}$ ed.; Regensburg: Manz, 1923), 365. 


\section{Characterisation}

In Ps 64 there are eight distinct characters: The lyrical "I" (1), the Deity (2), the enemies (3), the innocent (4), all who see this, i.e. the observers (5), all people (6), the just (7), and the upright in heart (8). In terms of the representation of these, three distinct groups emerge: (1) the enemies, (2) the lyrical "I" who is later described as the innocent and the just and is also part of those who are upright in heart as well as (3) a third, rather more neutral group containing all those who observe and all people. Let us now take a closer look at the enemies, the lyrical "I" and the Deity and their actions:

a Deity

The deity appears five times throughout the text (2a, $8 \mathrm{a}, 10 \mathrm{~b}, 11 \mathrm{a}, 11 \mathrm{~b})$, but only once as a subject and in an active capacity (8a). However, this brief action is enough to bring about the turning point in the story of the text.

In v. 2, the deity is asked for protection. The verb נצר carries the concrete meaning of watching over, preserving, guarding, i.e. in the context of a field (Job 27:18; $2 \mathrm{Kgs}$ 17:9) or fruit trees (Prov 27:18). In a figurative sense, it appears in connection with being spared from the sword or pestilence (Ezek 6:12) or delivered from evil (Prov 2:11-12; 4:6). Here in Ps 64 the request for נצר concerns God's care for the individual (as also in Isa 42:6; Pss 32:7; 40:12; 140:2.5; Prov 2:8). נצר does not just concern the sensory perception (including hearing), but also the action of safeguarding. ${ }^{16}$ This taking care of life can be found in a number of thanksgiving songs and laments only used when referring to the deity. YHWH is thus depicted as the one who is willing and able to protect and save those in need. At the end of the psalm the divine name of God, YHWH, is placed in an object position. This is where the just rejoices and takes shelter.

The image of God depicted in Ps 64 is initially shaped by the plea for attention (hearing) and for protection. The deity is thus the one who is able to perceive the situation of the praying "I", can turn towards him/her and grant $\mathrm{him} /$ her protection. YHWH is also the one who as an archer beats the enemies with their own weapons. The depiction of the deity firing an arrow in v. 8 is a continuation of the war metaphor in vv. 4-5. In vv. 4-5, the enemies are portrayed as warriors and hunters; here in v. 8 it is God. ${ }^{17}$ Mythical references to deities firing arrows in their fight against the dragon of chaos may also shine through here. ${ }^{18}$ However this image can be interpreted, it is an expression of confidence

\footnotetext{
15 Cf. Georg Sauer, "נצר," THAT 2, 100-101.

16 Cf. Siegfried Wagner, "נצרב," ThWAT 5, 579.

17 On the depiction of God as a warrior, cf. Pss 17:13; 35:2-3; 38:3.

18 Cf. Hossfeld and Zenger, Psalmen 51-100, 209.
} 
in God and his ability to break the life-destroying force of evil in order to protect his world as a place of life and the work of God (v. 10). ${ }^{19}$

A violent deed is attributed to the deity here in v. 8. According to David Firth the right to react and therefore to exert violence in the name of persecuted innocents resides with the deity alone. The issue here is to restore justice for the praying subject who has innocently suffered persecution. ${ }^{20}$ The dimensions of perception, protection, security and refuge are ascribed to the deity of Israel here, as are those of the power to act against and injure the enemies.

b Lyrical " $I$ "

Analysing the lyrical "I" in vv. 2-3, the innocent in v. 5 and the just and upright in heart in v. 11 as belonging to one group of characters, this group can be described as follows: At the beginning, the direct speech addressing God in vv. 2-3 provides an insight into the bleak and drastic situation of threat and fear. The praying subject pleads with God to save his/her life. As an innocent with ethically and morally impeccable lifestyle, he is shot at by his enemies (v. 5). In the end, however, his initial plea is answered: the just can rejoice in YHWH and finds refuge and protection with him; the upright in heart exalt. The theme of intractability, the plea for the preservation of life, protection and the joy with and through YHWH are very clearly connected to the lyrical "I". This is in stark contrast to the enemies with their devious and evil thoughts and deeds. By depicting in details the activities and plans of the enemies, they are seen as an anti-group one should distance oneself from, for one's own good and in order to preserve one's own identity. ${ }^{21}$ In contrast it is suggested that one should identify with the lyrical "I".22

\section{c Enemies}

Psalm 64 puts emphasis on the characterisation of the enemies. These are introduced using three different terms: enemy (אוֹי.. v, v. 2b qal nominalised participle sg.), evildoers (מְרֵעצים, v. 3a hip 'il participle pl.), as well as those doing

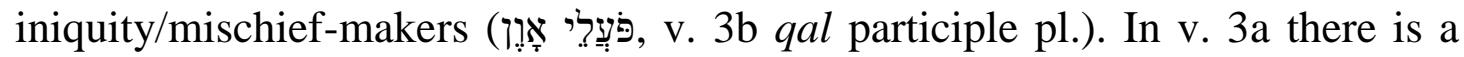

\footnotetext{
19 Cf. ibid., 209.

20 Cf. David G. Firth, Surrendering Retribution in the Psalms. Responses to Violence in Individual Complaints (PBM; Milton Keynes: Paternoster, 2005), 101.

21 Cf. Erhard S. Gerstenberger, Der bittende Mensch. Bittritual und Klagelied des Einzelnen im Alten Testament (WMANT 51; Neukirchen-Vluyn: Neukirchener, 1980), 160.

22 Cf. for more details Dorothea Erbele-Küster, Lesen als Akt des Betens. Eine Rezeptionsästhetik der Psalmen (WMANT 87; Neukirchen-Vluyn: Neukirchener, 2001; repr., Eugene, OR: Wipf and Stock, 2013), 114ff.
} 
mention of a gathering, which is indicative of the enemies acting together, like a horde, whereas the lyrical "I" is on his/her own. ${ }^{23}$

From v. 4 on, we find a description of what the enemies have done to be called exactly evildoers and mischief-makers. This is achieved by means of metaphoric speech which is characterised here by interlacing war and hunt motifs by making reference to sword(s) and arrow(s). Furthermore, the hunt is depicted by the arrow and the snares in v. 6. The motifs of war and hunt are also transferred to the enemies' speech (tongue v. 4a and v. 9a, bitter or evil word v. $4 \mathrm{~b}$ and v. 6a). First, the tongue is compared to a sword (cf. Ps 57:5). This comparison drastically shows the hurting dimension of words which - much like a sharp cutting edge of a sword - can inflict wounds. The enemies turn into warriors who draw swords in battle. While the sharpening of the blade is part of the preparation for war, stepping into the bow and placing the arrow point towards an imminent start of combat. Arrow and bow are both long-distance weapons belonging both to war and the hunt. The bow (קֶ), which is not mentioned here in v. 4, but is rather implied in the action of stepping (דרך), is used to shoot off (the arrow). It is bent by hand or - as in this case - by stemming the foot against the arc of the bow (Isa 5:28; Pss 7:13; 11:2; 37:14 a. o.). The actual weapon is the arrow whose point shall inflict deadly injury and is fitted accordingly, using materials such as flint, metal or poison.

Verse $4 \mathrm{~b}$ is characterised by a stylistic device which connects a verb (here: דרך to walk, to step) not with the adequate object (קְשָ bow, which in this instance is left out), but with the next object, in this case the arrow (cf. also Ps 58:8). The stepping on or bending of a bow and setting up the arrow is thus described as one single event instead of using two verbs (stepping; positioning) and two objects (bow; arrow). ${ }^{24}$

The enemies are shooting at the innocent with their words just as bowmen in a battle are shooting off their arrows. The arrow here is an image for the

23 As Clifford notes "It is not one but many enemies who are engaged in the destruction, and they operate anonymously with a complete disregard for justice" (Clifford, Psalms 1-72, 302). The fact that the enemies do not appear in singular, but are always referred to in plural forms, is not unusual in the psalms. More uncommon is their appearance in structured groups (gang, crowd, gathering). Cf. Gerstenberger, Der bittende Mensch, 159-160 with a reference to Pss 22:17; 26:5; 55:15; 86:14 and the like. 24 Cf. Weber, Werkbuch Psalmen 1, 285; Hans Schmidt, Die Psalmen (HAT 1/15; Tübingen: Mohr, 1934), 120 and Luis Alonso Schökel and Cecilia Carniti, Salmos 1 (Salmos 1-72). Traducción, introducciones y comentario (Nueva Biblia Española; $2^{\text {nd }}$ ed.; Estella / Navarra: Ed. Verbo Divino, 1994), 840. 
dangerous tongue and the deadly danger that can come from its words. ${ }^{25}$ The deadly words of the enemies are cutting and piercing. ${ }^{26}$

The readers learn a lot about the enemies, not just through the abovementioned descriptions, but also through the voice and the act of speaking which is granted to the enemies, as well as their inner perspective. This allows the readers to gain a deep insight into the character of the enemies. It also shows that the lyrical "I" has a clear picture of his/her enemies. The enemies gather and act as a group, a crowd, or a horde. They also appear as a noisy throng. They spread restlessness and fear, inflict injury through evil words and make themselves stronger through words. They appear self-assured, fearless, talk about their plans to set traps and foster bad thoughts and dark plans. Firth talks about the enemies as bringing both psychological and physical violence to bear on the lyrical "I". Initially, they subject him/her to psychological anguish through their threats; but eventually, they seek his/her physical death. ${ }^{27}$ Significantly, the enemies are themselves pierced by an arrow, wounded and made to stumble. Their tongue is thus turned against them. God beats them with their own weapons (arrow rn, tongue לְ⿱ $)$. The hunters become the hunted. ${ }^{28}$

Psalm 64 is characterised by a distinctive contrast: On the one hand there is the Deity and all people including the righteous, the innocent, all the upright in heart and the lyrical "I," who stick with YHWH, on the other hand there are the enemies, who as evildoers and mischief-makers evoke threat, injury, unrest and trouble.

Much of what the enemies do, comes back to haunt them: ${ }^{29}$ they aim with their arrows (v. 4b), but they hit themselves (v. 8a); they shoot unexpectedly (suddenly פְִּ ve v. 8b). The enemies lay a trap for the other (v. 6b) only to be tripped themselves (v. 9a); they encourage each other in doing evil and try to conceal

25 The comparison of evil words and arrows is already known (Pss 7:13-14; 11:2; 37:14; 52:4; 57:5; 59:8). Cf. Othmar Keel, Feinde und Gottesleugner: Studien zum Image der Widersacher in den Individualpsalmen (SBM 7; Stuttgart: Katholisches Bibelwerk, 1969), 171.

26 Cf. Gerald H. Wilson, Psalms, Volume 1 (NIVAC; Grand Rapids, MI: Zondervan, 2002), 899.

27 Cf. Firth, Surrendering Retribution in the Psalms, 98: "The imagery of ambush and stalking of the psalmist contribute to the psalm by developing the reader's awareness of the fact that there is a continued process of hunting going on in which the 'trophy' is the death of the psalmist."

28 Cf. Manfred Oeming and Joachim Vette, Das Buch der Psalmen: Psalm 42-89 (NSK.AT 13/2; Stuttgart: Katholisches Bibelwerk, 2010), 138.

29 Cf. Pss 7:17; 9:16; 35:8; 57:7; 141:10; Prov 26:27, and Weiser, Psalmen 1, 312. Similarly, Riede, Im Netz des Jägers, 367. 
their snares (vv. 5a, 6c) only to fall by publicly by their own snares (v. 9b); and they show no fear (v. 5b) whereas God deserves to be feared (v. 10a).

The enemies can stand for the personal threat posed to the lyrical "I" by a group of people intending to harm him/her through words and deeds. However, they may also stand for the menacing power of death. Psalm 64 thus ultimately deals with the fight against the power of death through the life protecting (see 2b) God. ${ }^{30}$

\section{$5 \quad$ Time and space}

To conclude the narratological analysis of Ps 64, let us have a look at terms relating to space and time (see 2. Narratology): The time aspect is expressed in the adverb of time "suddenly, immediately, unawares" (פְּּ $5 \mathrm{~b} ; 8 \mathrm{~b}$ ). This is a stylistic device which helps to heighten the tension, describes the suddenness and the moment of surprise when an ominous event happens. The reference to a place can be found in 5a: The expression "is "in hiding "in obscurity" is on the one hand a characterisation of the deeds of the enemies. They act secretly instead of seeking a direct face-to-face confrontation. On the other hand the expression "in hiding" also stands for the lyrical "I"'s longing for protection and safety (3a).

\section{CONCLUSIONS}

After this study of Ps 64, what are the findings related to the limits and chances of a narrative psalm analysis?

\section{The merits of narratology}

In general, we can say that "... narratology has generally enriched the toolkit for the close reading of texts. Classical texts have been read and interpreted for centuries and every new set of scholarly 'spectacles' that opens our eyes to new facets is welcome." "31 According to Ansgar and Vera Nünning, the defined terminology, clear methodology, the descriptivity, and the falsifiability of conceptual structures are among the main advantages of narratology. ${ }^{32}$

30 Cf. Hossfeld and Zenger, Psalmen 51-100, 204, referring to Pss 59; 64; 73 and 94; Keel, Feinde und Gottesleugner, 172, also talks about the effective power of God.

31 Irene J. De Jong, Narratology and Classics: A Practical Guide (Oxford: Oxford University Press, 2014), 10.

32 Cf. Ansgar and Vera Nünning, "Von der strukturalistischen Narratologie zur 'postklassischen' Erzähltheorie: Ein Überblick über neue Ansätze und Entwicklungstendenzen," in Neue Ansätze in der Erzähltheorie (WVT-Handbücher zum literaturwissenschaftlichen Studium 4; ed. Ansgar and Vera Nünning, Trier: Wissenschaftlicher Verlag, 2002), 1-33 (1, 5). 
The narrative analysis of characters and their actions, times, spaces and movements also pulls analysts closer to the text, as they are forced to study the structure of the text a lot more closely. In this context, the tracing of movements and the characterisation in the text, especially of the lyrical "I", should be emphasised here. The analysis of the story in connection with the narrative impulses within the parallelisms has basically brought the movements in Ps 64 and the events contained therein into sharper focus.

\section{$2 \quad$ Limits of a narrative psalm analysis}

Does this mean that all psalms can be subjected to narrative analysis? This is not the case. Narrative analysis of the exegesis of psalms reaches its limit when there is no discernible sequence of events, i.e. when there are no two events following each other, such as is the case e.g. in Ps 90 from v. 12 onwards, when a series of imperatives are introduced and dominate the text. Narrativity (i.e. the characteristic of a story) fades into the background so that the narrative categories of analysis are not effective anymore.

Furthermore, for a full understanding of a biblical text, it is not enough to analyse it with the method of narrative analysis. Narrative analysis opens perspectives for analysing the depth and richness of a text and contributes to a better and deeper understanding.

For the understanding of psalms, it is also vital to clearly describe metaphors and semantics. In a narrative analysis these have to be included in the characterisation, such as in our case in the analysis of the lyrical "I", the Deity and the enemies, and here especially in the study of metaphorical language applied in the comparison of the tongue and the sword and the arrow with a bitter word in v. 4.

\section{Opportunities provided by a narrative psalm analysis}

By taking a close look at the narrative voice and subjecting it to the same analysis as a character, the lyrical "I" of the psalm becomes much clearer. The lyrical subject, who at the beginning of the text is semantically undefined, acquires a distinct shape and a clearer profile through narrative analysis. It becomes clear who this is and what he or she does with which intentions. This enables readers to define the lyrical "I" much more precisely. The lyrical "I" of Ps 64 forms a group of characters together with the innocent, the righteous and the upright in heart. It is characterised by asking the Deity for protection and safeguard and is making an urgent plea. The lyrical "I" has a clear and differentiated image of the enemies and knows them well. As an innocent, it is shot at by the enemies, as the just, it finally reaches safety with God, as part of the upright in heart it rejoices and exalts. The clearer definition of the lyrical "I" has to be seen as an especially profitable element when carrying out a narrative 
analysis of poetic texts. ${ }^{33}$ To conclude this field of characterisation, it should also be noted that the narrative analysis takes God seriously as a character on which it also focuses. ${ }^{34}$ The narrative analysis of the Deity of Israel leads into the tension field where God is on the one hand treated as a character among others, while on the other hand the possibly special character of God who as an unfathomable power transcends human standards is also surveyed.

In Ps 64, the deity is characterised by listening and perceiving, providing protection, shelter and joy. In the text, YHWH like the enemies shoots and injures. However, for the most part in this text, YHWH is a character like no other. God is the only one who can grant protection as it is evident in v. 2. YHWH also stands above the enemies. The Deity of Israel frees the praying person from a situation of persecution and distress by stepping in in a powerful manner and by performing only a single act. The Deity is thus a character like no other, as YHWH is the only one who can put an end to the violence of the enemies and the threat to life thereby saving the lyrical "I" from his/her possible death.

\section{BIBLIOGRAPHY}

Alonso Schökel, Luis and Carniti, Cecilia. Salmos 1 (Salmos 1-72): Traducción, introducciones y comentario. Nueva Biblia Española. $2^{\text {nd }}$ ed. Estella / Navarra: Ed. Verbo Divino, 1994.

Bleumer, Hartmut and Emmelius, Caroline. "Generische Transgressionen und Interferenzen. Theoretische Konzepte und historische Phänomene.” Pages 1-39 in Lyrische Narrationen - narrative Lyrik. Gattungsinterferenzen in der mittelalterlichen Literatur. Edited by Hartmut Bleumer and Caroline Emmelius. Trends in Medieval Philology 16. Berlin et al.: De Gruyter, 2011. https://doi.org/ 10.1515/9783110215922.1.

Botha, Phil J. "The Textual Strategy and Social Background of Psalm 64 as Key to its Interpretation." Journal for Semitics 11 (2002): 64-82.

Clifford, Richard J. Psalms 1-72. Abingdon Old Testament Commentaries. Nashville, TN: Abingdon Press, 2002.

De Jong, Irene J. Narratology and Classics. A Practical Guide. Oxford: Oxford University Press, 2014.

Eder, Sigrid, Identifikationspotenziale in den Psalmen. Emotionen, Metaphern und Textdynamik in den Psalmen 30, 64, 90 und 147. Bonner Biblische Beiträge 183. $2^{\text {nd }}$ ed. Göttingen: Vandenhoeck \& Ruprecht, 2019). DOI: https://www.vrelibrary.de/doi/book/10.14220/9783737006842.

33 Cf. Hartmut Bleumer and Caroline Emmelius, "Generische Transgressionen und Interferenzen. Theoretische Konzepte und historische Phänomene, "in Lyrische Narrationen - narrative Lyrik. Gattungsinterferenzen in der mittelalterlichen Literatur (ed. Hartmut Bleumer and Caroline Emmelius; Berlin et al.: De Gruyter, 2011), 16.

34 Cf. the anthology by Ute E. Eisen and Ilse Müllner (eds.), Gott als Figur. Narratologische Analysen biblischer Texte und ihrer Adaptionen (Freiburg et al.: Herder, 2016). 
Eisen, Ute E. and Müllner, Ilse (eds.), Gott als Figur. Narratologische Analysen biblischer Texte und ihrer Adaptionen. HBS 82. Freiburg et al.: Herder, 2016.

Erbele-Küster, Dorothea. Lesen als Akt des Betens. Eine Rezeptionsästhetik der Psalmen. Wissenschaftliche Monographien zum Alten und Neuen Testament 87. Neukirchen-Vluyn: Neukirchener, 2001. Repr., Eugene, OR: Wipf and Stock, 2013.

Firth, David G. Surrendering Retribution in the Psalms. Responses to Violence in Individual Complaints. Paternoster Biblical Monographs. Milton Keynes: Paternoster, 2005.

Fischer, Stefan. Das Hohelied Salomos zwischen Poesie und Erzählung. Erzähltextanalyse eines poetischen Textes. Forschungen zum Alten Testament 72. Tübingen: Mohr Siebeck, 2010.

Fludernik, Monika. An Introduction to Narratology. London / New York, NY: Routledge, 2009.

Fokkelman, Jan P. The Psalms in Form. The Hebrew Psalter in its Poetic Shape. Tools for Biblical Study Series 4. Leiden: Deo, 2002.

Gerstenberger, Erhard S. Der bittende Mensch. Bittritual und Klagelied des Einzelnen im Alten Testament. Wissenschaftliche Monographien zum Alten und Neuen Testament 51. Neukirchen-Vluyn: Neukirchener, 1980.

Hossfeld, Frank-Lother and Zenger, Erich: Psalmen 51-100. Herders theologischer Kommentar zum Alten Testament. Freiburg: Herder, 2000.

Hühn, Peter and Sommer, Roy. "Narration in Poetry and Drama Paragraph 2." Pages 419-434 in The Living Handbook of Narratology (2016 Edition). Edited by Peter Hühn et al. https://doi.org/10.1515/9783110316469.419.

Keel, Othmar. Feinde und Gottesleugner: Studien zum Image der Widersacher in den Individualpsalmen. Stuttgarter Biblische Monographien 7. Stuttgart: Katholisches Bibelwerk, 1969.

Lahn, Silke and Meister, Jan C. Einführung in die Erzähltextanalyse. $2^{\text {nd }}$ ed. Stuttgart: J.B. Metzler, 2013.

Müllner, Ilse. "Zeit, Raum, Figuren, Blick. Hermeneutische und methodische Grundlagen der Analyse biblischer Erzähltexte," Protokolle zur Bibel 15 (2006): $1-24$.

Nünning, Ansgar and Nünning, Vera. "Von der strukturalistischen Narratologie zur 'postklassischen' Erzähltheorie: Ein Überblick über neue Ansätze und Entwicklungstendenzen." Pages 1-33 in Neue Ansätze in der Erzähltheorie. Edited by Ansgar und Vera Nünning. WVT-Handbücher zum literaturwissenschaftlichen Studium 4. Trier: Wissenschaftlicher Verlag, 2002.

Oeming, Manfred and Vette, Joachim. Das Buch der Psalmen: Psalm 42-89. Neuer Stuttgarter Kommentar, Altes Testament 13/2. Stuttgart: Katholisches Bibelwerk, 2010.

Riede, Peter. Im Netz des Jägers. Studien zur Feindmetaphorik der Individualpsalmen. Wissenschaftliche Monographien zum Alten und Neuen Testament 85. Neukirchen-Vluyn: Neukirchener, 2000.

Sauer, Georg. "נצר." Pages 99-101 in vol. 2 of Theologisches Handwörterbuch zum Alten Testament. Edited by Ernst Jenni and Claus Westermann, 2 vols. Gütersloh: Kaiser, 1976.

Schmid, Wolf. Elemente der Narratologie. $2^{\text {nd }}$ ed. Berlin: De Gruyter, 2008. 
Schmidt, Hans. Die Psalmen. Handbuch zum Alten Testament 1/15. Tübingen: Mohr, 1934.

Schönert, Jörg. "Was ist und was leistet Narratologie? Anmerkungen zur Geschichte der Erzählforschung und ihrer Perspektiven," Literaturkritik 8(4) (2006). https://literaturkritik.de/id/9336.

Thalhofer, Valentin. Erklärung der Psalmen und der im römischen Brevier vorkommenden biblischen Cantica, mit besonderer Rücksicht auf deren liturgischen Gebrauch. $9^{\text {th }}$ ed. Regensburg: Manz, 1923.

Thöne, Yvonne. Liebe zwischen Stadt und Feld. Raum und Geschlecht im Hohelied. Exegese in unserer Zeit 22. Berlin: LIT, 2012.

Thöne, Yvonne. "Stay in the Desert, Prowl in the City. A Narratological Analysis of Psalm 55." Pages 55-73 in Mótun menningar: afmalisrit til heiðurs Gunnlaugi A. Jónssyni sextugum = Shaping Culture: A Festschrift in Honor of Gunnlaugur A. Jónsson on his Sixtieth Birthday. Edited by K. Ólason et al. Reykjavík: Hiđ Íslenska Bókmenntafélag, 2012.

Wagner, Siegfried. "נצר." Pages 577-587 in vol. 5 of Theologisches Wörterbuch zum Alten Testament. Edited by G. Johannes Botterweck and Helmer Ringgren. 8 vols. Stuttgart: Kohlhammer, 1986.

Weber, Beat. Werkbuch Psalmen 1. Die Psalmen 1 bis 72. Stuttgart: Kohlhammer, 2001.

Weiser, Artur. Die Psalmen, 1. Teil. Altes Testament Deutsch 14. $9^{\text {th }}$ ed. Göttingen: Vandenhoeck \& Ruprecht, 1979.

Wilson, Gerald H. Psalms, Volume 1. New International Version Application Commentary. Grand Rapids, MI: Zondervan, 2002.

Dr (Univ Doz) Sigrid Eder, Catholic Private University Linz, Austria, Email: s.eder@ku-linz.at. ORCID: https://orcid.org/0000-0002-3651-5028. 